\title{
ArcheoSciences
}

Revue d'archéométrie

$30 \mid 2006$

Varia

\section{Archaeometric research on the Early Neolithic pottery production in Liguria (Northern Italy): preliminary data from San Sebastiano di Perti (Savona)}

Recherche archéométrique sur la production de poteries du Néolithique ancien en Ligurie (Italie du Nord) : données nouvelles préliminaires de San Sebastiano di Perti (Savone)

Claudio Capelli, Elisabetta Starnini, Roberto Cabella and Michele Piazza

\section{CpenEdition}

Journals

Electronic version

URL: https://journals.openedition.org/archeosciences/207

DOI: 10.4000/archeosciences.207

ISBN: 978-2-7535-1595-6

ISSN: 2104-3728

Publisher

Presses universitaires de Rennes

Printed version

Date of publication: 31 December 2006

Number of pages: 89-94

ISBN: 978-2-7535-0456-1

ISSN: $1960-1360$

Electronic reference

Claudio Capelli, Elisabetta Starnini, Roberto Cabella and Michele Piazza, "Archaeometric research on the Early Neolithic pottery production in Liguria (Northern Italy): preliminary data from San Sebastiano di Perti (Savona)", ArcheoSciences [Online], 30 | 2006, document 8, Online since 31 December 2008, connection on 27 January 2022. URL: http://journals.openedition.org/archeosciences/207 ; DOI: https://doi.org/10.4000/archeosciences.207 


\title{
Archaeometric research on the Early Neolithic pottery production in Liguria (Northern Italy): preliminary data from San Sebastiano di Perti (Savona)
}

\author{
Claudio Capelli*, Elisabetta Starnini**, Roberto Cabella* and Michele Piazza*
}

\begin{abstract}
The Early Neolithic site of San Sebastiano di Perti is the only open-air site of the Impressed Ware Culture so far discovered in Liguria. It is located in the Finalese area, on a river terrace along the Pora Valley. One radiocarbon AMS date of 6760 \pm 45 BP (GrA-25715) was obtained from two caryopsis of Hordeum vulgare. The ceramic assemblage consists of 123 potsherds mainly decorated with impressions from Cardium shell and with implements; six representative samples have been submitted for thin-section analyses. The petrographic characteristics of the inclusions are consistent with those of the acid metavolcanites and metasediments of the Permo-Carboniferous basement and of the Miocenic limestones outcropping in the area. A local production and the use of raw materials of fluvial origin (from the Pora River) can be hypothesised. The San Sebastiano production differs in textural, compositional and technical features from other ceramic contexts of neighbouring cave sites of the same chronology and Culture studied so far. In particular, it is important to point out the absence at San Sebastiano of fabrics with crushed calcite temper, that are on the contrary frequent, for instance, at the Arene Candide Cave.
\end{abstract}

Résumé : Le site du Néolithique ancien de San Sebastiano di Perti représente le seul site de la Culture de la Céramique Imprimée connu en Ligurie. Il se trouve dans le Finalese, sur une terrasse fuviale dans la vallée du Pora. Un âge de 6760 45 BP (GrA-25715) a été obtenu sur deux caryopses de Hordeum vulgare par datation radiométrique AMS. L'ensemble des céramiques récoltées est composé de 123 fragments, dont la majorité est décorée par impressions de coquilles de Cardium et sillons. Six échantillons représentatifs ont été analysés en lame mince. Les caractéristiques pétrographiques des inclusions sont compatibles avec celles des métavolcanites acides et des métasédiments du socle Permo-Carbonifere et des calcaires du Miocène affleurant dans les environs. On peut supposer une production locale de la céramique avec matières premières d'origine fluviale. La production de San Sebastiano est différente des autres productions de la même chronologie, étudiés jusqu’à présent, trouvées dans les grottes du Finalese. On souligne en particulier l'absence à San Sebastiano de pâtes avec calcite broyée, qui est au contraire employée comme dégraissant, par exemple, dans la production des Arene Candide.

Key words: AMS radiocarbon dating, Early Neolithic pottery, Liguria, Northern Italy, petrographic thin-section analyses.

Mots-clés: Pétrographie, lame mince, céramique, Néolithique ancien, datation AMS, Italie du Nord, Ligurie.

\section{INTRODUCTION}

The Early Neolithic site of San Sebastiano di Perti is the only Impressed Ware Culture open-air site so far known in Liguria. It is located in the Finalese region, on a river terrace of the Pora Valley, $3 \mathrm{~km}$ from the present coastline (Fig. 1, 2). The site was discovered by pupils of the local elementary school who collected one greenstone polished

\footnotetext{
* Dipartimento per lo Studio del Territorio e delle sue Risorse (DIPTERIS), Università degli Studi di Genova, Corso Europa 26, 16132 Genova (Italy). (capelli@dipteris.unige.it)

** Soprintendenza per i Beni Archeologici della Liguria, via Balbi 10, 16126 Genova (Italy). (elisabetta.starnini@beniculturali.it)
} 

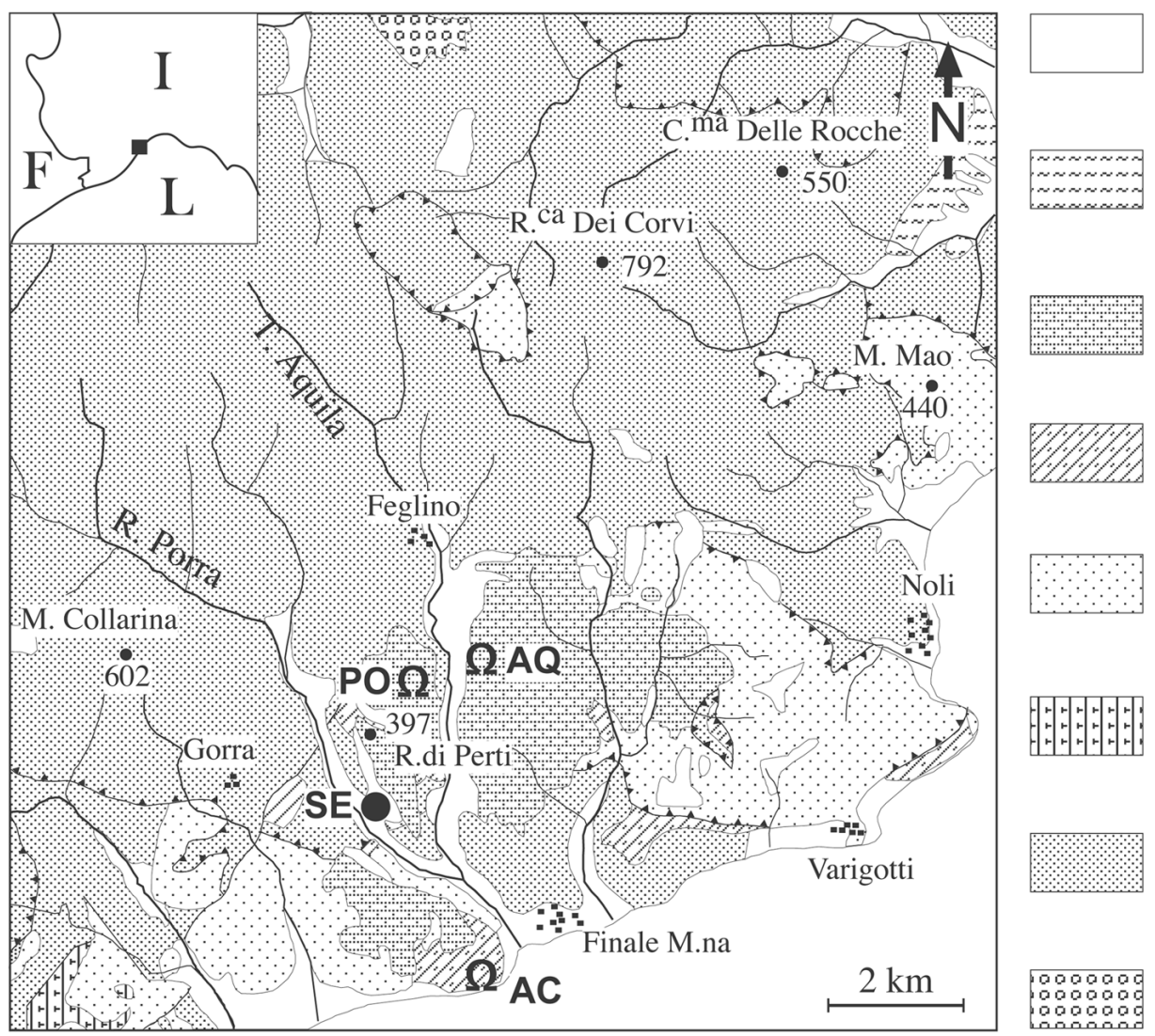

1 - Recent non-marine and littoral deposits; Holocene

2 - Ortovero Clay; Pliocene

3 - "Pietra di Finale"; upper Oligocene - middle Miocene

4 - Val Tanarello Limestone; upper Jurassic

5 - Ponte di Nava Sandstone; San Pietro dei Monti Dolostone; lower - middle Triassic

6 - M. Pianosa Fm.; upper Permian - lower Triassic

7 - Melogno Phorphyry; Eze Fm.; Gorra Fm.; Murialdo Fm.; upper Carboniferous lower Permian

Figure 1: Geological sketch of the Finalese with the location of the most important Impressed Ware sites known in the area; AC: Arene Candide Cave; AQ: Arma dell'Aquila; PO: Pollera Cave; SE: San Sebastiano di Perti (redrawn and modified from Giammarino et al., 2002).

Figure 1: Carte géologique du Finalese montrant la localisation des plus importants sites à céramique imprimée connu dans la région.

axe blade in 1980 (Starnini \& Vicino, 1993). An archaeological survey conducted soon after revealed that the building of a terracing wall, in the backyard of the school, had exposed the profile of the slope for a few metres: it brought to light an archaeological black layer containing several prehistoric potsherds, marine shells and animal bones (Ovis vel Capra, Sus scrofa L., Cervus elaphus L.; Sorrentino, pers. comm.). Although no extensive excavation has been so far carried out at this site, a few samples have been recently collected from the profile, among which one soil specimen for archaeobotanical analysis. Charcoals and a few cereal seeds were recovered by flotation. The practice of agriculture is indicated by the occurrence of Hordeum vulgare var. nudum and Triticum dicoccum caryopses (Arobba \& Vicino, 1997-99). Two caryopses of Hordeum vulgare collected at San Sebastiano di Perti have been submitted for an AMS radiocarbon dating, which gave the result of $6760 \pm 45 \mathrm{BP}$ (GrA-25715). The date, which perfectly fits with the associated material culture, indicates that the site was occupied around $5730-5610 \mathrm{cal} \mathrm{BC}(2 \sigma, 90.9 \%$ probability) (Stuiver et al., 1998). The available data show that further research is highly needed for a better understanding of the chronological sequence of the Early Neolithic of the study region. In effect, following the recent proposal of two Early Neolithic phases in Eastern Provence and Liguria, on the basis of different stylistic characteristics of the pottery assemblage (Binder \& Maggi, 2001), S. Sebastiano would fall in the second phase, which is characterised by the predominance of Cardium decorated pottery. However, the AMS date clearly demonstrates that the site was occupied during the first of the proposed phases.

The archaeometric analysis has been carried out with the aim of increasing information on the pottery production of the Early Neolithic Impressed Ware Culture in Liguria and in particular, to compare the data obtained from San Sebastiano with those already available from the neighbouring sites of Arene Candide and Pollera caves (Ferraris \& Ottomano, 1997; Mannoni, 1990). 


\section{The geOlogical SETTING}

The Finale Ligure area ("Finalese") is located in the Ligurian Alps. Its geological setting is largely dominated by tectonic units of the Briançonnais Domain, which are unconformably overlain by post-orogenic and recent sedimentary deposits (Fig. 1). The following short descriptions of these three geological units are derived from Boni et al. (1968; 1971), Boni (1984), Vanossi et al. (1984), Cortesogno \& Vanossi (1985), Vanossi (1990), and Giammarino et al. (2002).

Recent non-marine and littoral deposits (1 in Fig. 1). This unit is represented by fine to coarse grained alluvial sediments, sandy and gravelly beach deposits, eluvial and colluvial deposits (Holocene).

Post-orogenic marine deposits. This unit outcrops along the Ligurian coast and unconformably overlies the Alpine Units although it is not involved in the Alpine Orogeny. It includes two main sedimentary sequences: a) marly and silty-marly grey-blue clays, silty and sandy clays, with minor conglomeratic bodies (2 in Fig. 1; Ortovero Clay; Pliocene); b) bioclastic limestones, coquinoid limestones, shell beds, sandy limestones, marls, siltstones, sandstones, conglomerates and breccias (3 in Fig. 1; Finale Ligure Limestone = "Pietra di Finale"; upper Oligocene - middle Miocene).

Briançonnais Domain. It includes I) crystalline basement units (pre-upper Carboniferous); II) upper Carboniferous lower Triassic volcano-sedimentary units (“tegumento”); III) lower Triassic - Paleogene sedimentary units ("copertura”).

No basement units (I) outcrop in the study area. Conversely, volcano-sedimentary units (II) largely occur. They are mainly composed of: a) graphitic phyllades, coarse fluvial metasediments and minor rhyolitic tuffs (8 in Fig. 1; Ollano Fm., upper Carboniferous); b) metarhyolites; meta-andesites; micaceous quartz fine-grained metasediments, rhyolitic tuffs and pyroclastic deposits; blackish graphitic phyllades with interbedded grey-greenish sandstones (7 in Fig. 1; Melogno Porphyry; Eze Fm.; Gorra Fm.; Murialdo Fm.; upper Carboniferous - lower Permian); c) micaceous quartz sandstones and conglomerates with abundant rhyolite pebbles and grains (6 in Fig. 1; M. Pianosa Fm.; upper Permian - lower Triassic). The sedimentary units (III) are well exposed and mainly formed by a) quartz sandstones and conglomerates; dolostones and dolomitic limestones (5 in Fig. 1; Ponte di Nava Sandstone; San Pietro dei Monti Dolostone; lower middle Triassic); b) recrystallized, whitish or pink limestones, with minor red nodular limestones and hardground deposits (4 in Fig. 1; Val Tanarello Limestone; upper Jurassic).

The prehistoric site of S. Sebastiano is located on an ancient fluvial terrace a few metres above the present-day river bed (Fig. 3). It lies at the base of a slope whose original morphology is strongly altered by ancient and modern terracing and dry stone walls, constructed for agricultural purposes (Fig. 2). Sedimentary and metamorphic rocks, together with alluvial, eluvial, and colluvial sediments outcrop in the surroundings (Fig. 3).

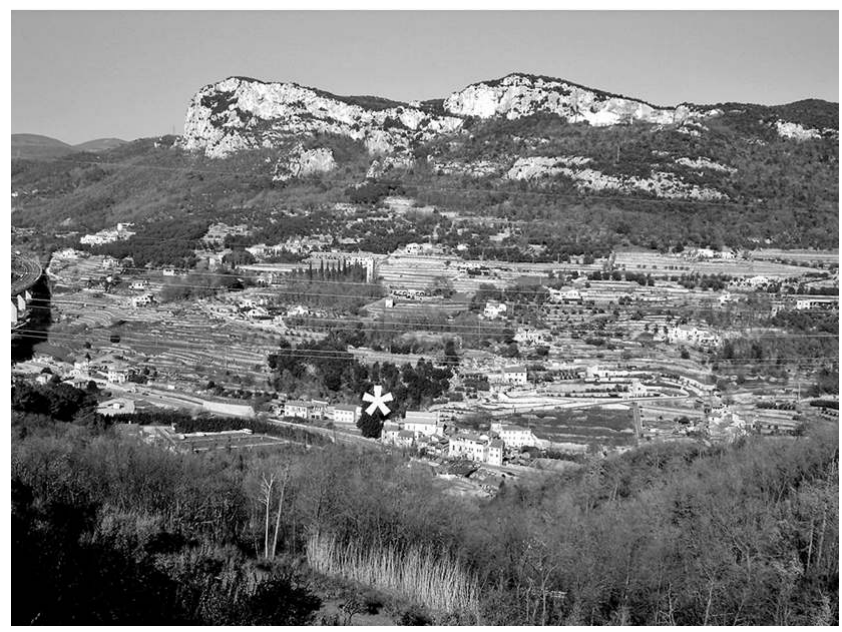

Figure 2: Panoramic view of the Pora Valley with the terrace where the site of San Sebastiano (white asterisk) is located.

Figure 2: Vue panoramique de la vallée de Pora avec la localisation (par un astérisque) du site de San Sebastiano.

\section{The arChaEOLOGICAL AND ARCHAEOMETRIC CHARACTERIZATION OF THE CERAMIC ASSEMBLAGE}

The pottery assemblage consists of 123 sherds. From a stylistic point of view, it is characterized by both instrumental and Cardium impressed patterns, with a predominance of the latter (Starnini \& Vicino, 1993; Fig. 2). The sequential impressed decoration (sillons d'impressions) is also represented. The colour of the ceramic surfaces varies from reddish brown (5YR 5.5/4) to dark grey (5Y 4/1). The wall thickness ranges between 7 and $17 \mathrm{~mm}$, suggesting the presence of vessels of different function.

After observation with the stereomicroscope of all the ceramic assemblage, six representative samples have been submitted for the thin-section analysis. The selections have been made on the basis of the shape, decoration and macroscopic characteristics of the fabrics (Fig. 4A-C). One sample of fired clay plaster (daub) has also been analysed as a reference of probably local raw materials.

The fabric of the daub is composed of a Fe-rich matrix and abundant, poorly sorted, angular to sub-angular inclusions measuring up to more than $1 \mathrm{~mm}$. They consist mainly of quartz grains and quartz-schist fragments (Fig. 5A); quartz- 

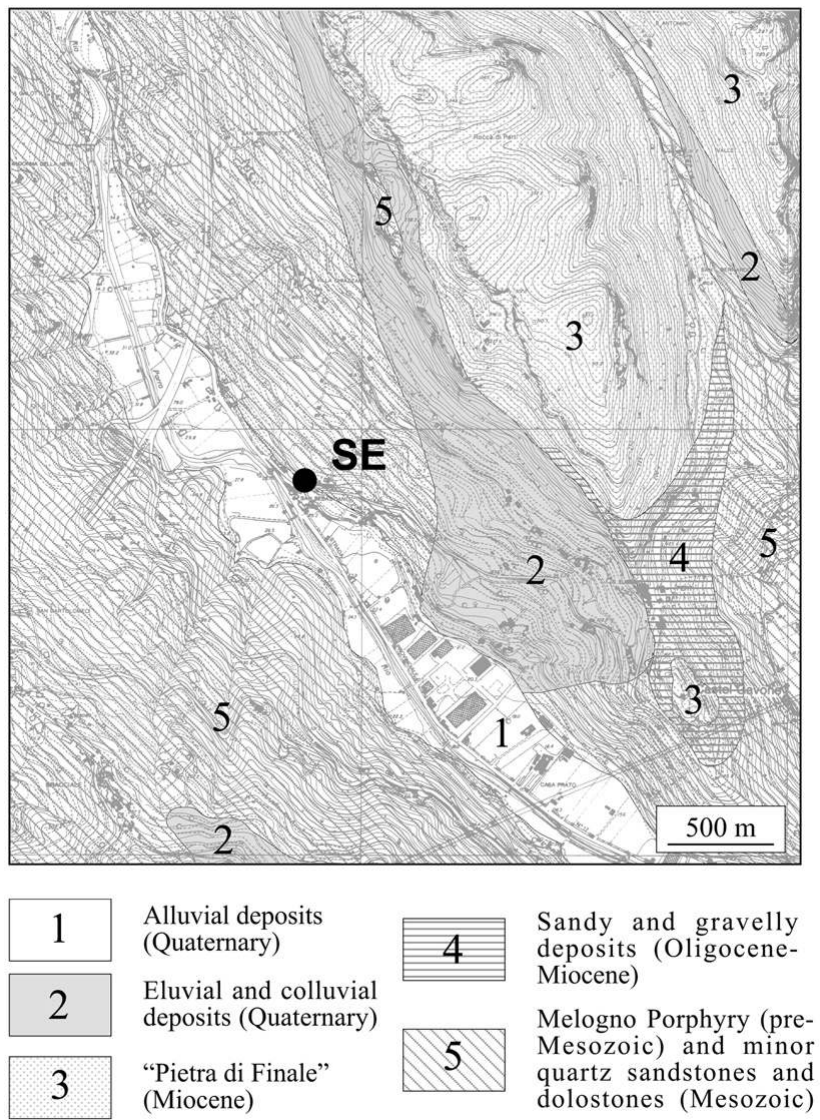

Figure 3: Geological map of the Pora Valley with the location of the Impressed Ware site of San Sebastiano (redrawn and modified from Boni et al., 1968).

Figure 3: Carte géologique de la vallée de Pora avec la localisation du site de San Sebastiano.

micaschist, micaschist and phyllite fragments and K-feldspar, plagioclase and mica individuals are subordinated; amphibole and epidote are accessory. Several organic inclusions (vegetal fragments) are also present (Fig. 5B).

In general, the fabrics of the analysed potsherds (Fig. 4) look like each other and are rather similar to that of the daub. The main difference is the presence of vegetal inclusions and charred wood in the latter. A certain variability exists in textural features and petrographic composition of the pottery fabrics: the texture is poorly- to well-sorted; the maximal dimensions of the inclusions range from 0.2-0.5 $\mathrm{mm}$ to $1-3 \mathrm{~mm}$; the percentage of the temper is moderate to very abundant (up to 50-70\%); in some cases the occasional presence of relict quartz grains with volcanic features (Fig. 4C) and limestone, acid and basic metavolcanic clasts can be observed. The oxidation degree is variable, often also through the section of the same sample, due to uneven firing conditions.
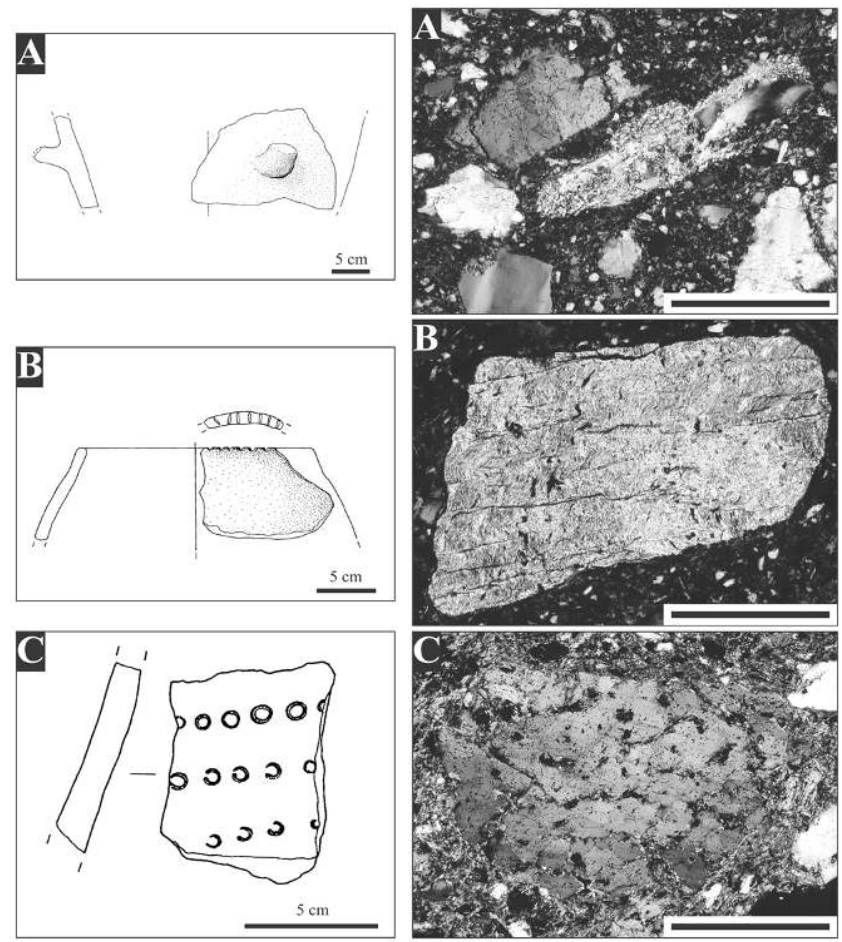

Figure 4: Drawings of some analyzed potsherds (left) and particulars of the corresponding fabrics in thin section (right) from San Sebastiano di Perti. A: body sherd of large vessel with lug; quartz-micaschist and quartzite fragments in a Fe-rich, fine grained matrix; B: rim fragment of a closed bowl; phyllite fragment; C: body sherd with impressed decoration; relict quartz grain of volcanic origin (NX, scale bar $500 \mu \mathrm{m}$ ).

Figure 4 : Dessins de quelques céramiques provenant de San Sebastiano di Perti (gauche) et particularités de leur pâte en lame mince (droite).

Despite the observed variability, all the pottery samples could be referred to the same production group. All the fabrics are probably made of alluvial clays, with an intentional addition of temper (alluvial sand) in some cases. The comparison between the temper composition and the regional geology suggests a provenance of the raw materials from the Finalese area. The metamorphic inclusions are in fact to be related to the metavolcanics and metasediments of the upper Carboniferous - lower Permian Formations of the Briançonnais Domain (see $\$$ Geological setting, IIb and Fig. 1), while the rare limestone fragments are related to the "Pietra di Finale".

Considering, in addition, the petrographic similarities observed in the comparative analyses of the pottery samples with the daub, it can be hypothesised that the sources of the raw materials used for the ceramic production were located in the proximity of the site. 

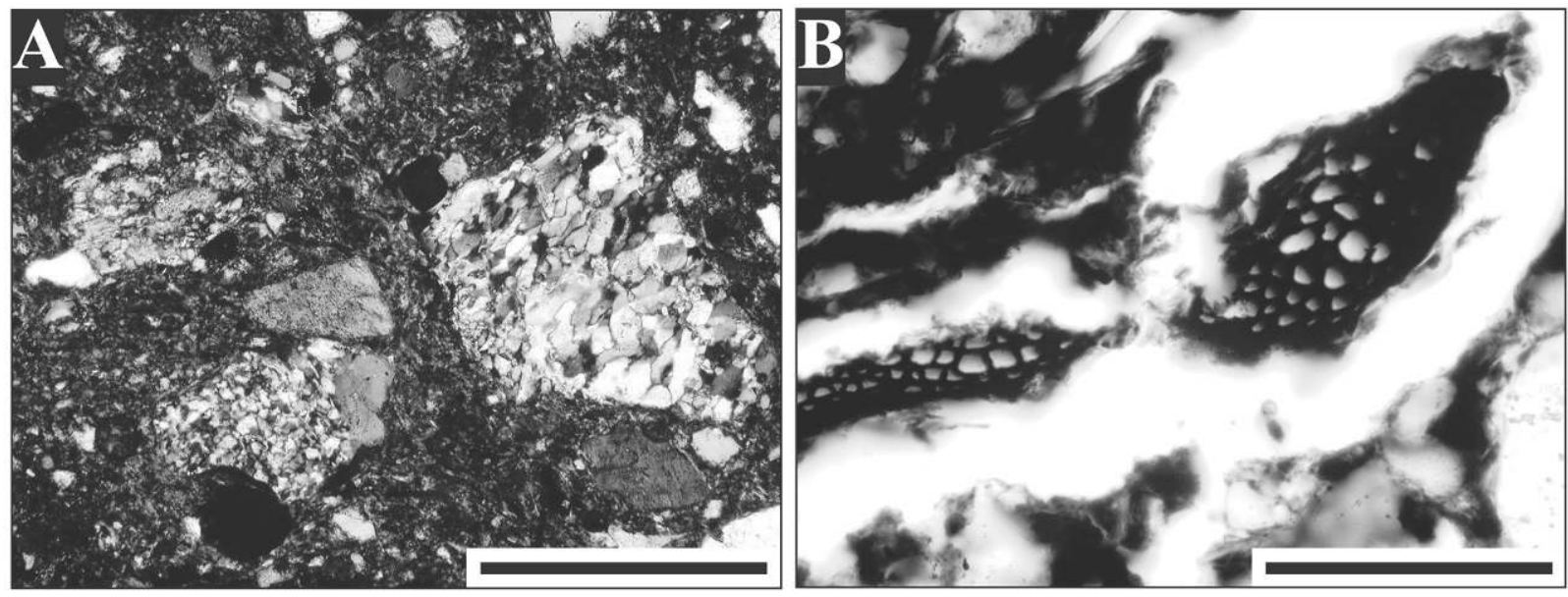

Figure 5: Microphotograph of the daub sample. A: NX, metamorphic inclusions are evident; scale bar: $500 \mu \mathrm{m}$. B: NP, charred wood particles; scale bar: $120 \mu \mathrm{m}$.

Figure 5 : Microphotographie d'un échantillon d'enduit.

\section{Discussion and CONClusions}

At present, only the ceramic assemblages of other two sites of the Impressed Ware Culture in Liguria have been studied with an archaeometric approach. These analyses were carried out on samples from the Arene Candide and Pollera caves (Ottomano \& Ferraris, 1997; Mannoni, 1990), both located in the Finalese, not far from San Sebastiano, one along the present coastline and the second in the Aquila Valley (Fig. 1, AC, PO). The thin sections from these two cave-sites, represented respectively by 18 and 2 specimens, were re-examined in the framework of a comparative study with San Sebastiano. All the fabric samples from the Arene Candide and Pollera that can be attributed to local productions are characterized by the presence of sparry calcite angular inclusions as a dominant or accessory component, associated with metamorphic inclusions. Moreover, among the samples from Arene Candide, there are some imported ceramics. A few of them have a long distance provenance (Capelli et al., 2006): this is a phenomenon that does not seem to occur at San Sebastiano.

The San Sebastiano pottery production partly or totally differs for texture, composition and technical features from the ceramic assemblages recovered from contemporary neighbouring cave sites of the same Culture. It is worthy of note the lacking of wares with crushed calcite temper in the San Sebastiano pottery production.

Concluding, the pottery assemblage from San Sebastiano seems to represent a peculiar production context. This could be explained by its different setting, being the only open air settlement so far known in the Finalese area.

\section{Acknowledgements}

The authors are grateful to two anonimous referees who improved the first draft of this paper. This work has been carried out in the framework of a Research Cooperation Program between the DIPTERIS (University of Genova) and the Soprintendenza per i Beni Archeologici della Liguria.

\section{References}

Arobba D. and Vicino G., 1997-99. Segnalazione di macroresti botanici nel sito neolitico di S. Sebastiano di Perti (SV). Bollettino dei Musei Civici Genovesi, XIX/XXI, (55/63): 29-37.

Binder D. and MAGgi R., 2001. Le Néolithique ancien de l'arc liguro-provençal. Bulletin de la Société Préhistorique Française, 98, (3): 411-422.

Boni A., 1984. Il Pliocene e la Neotettonica nelle Alpi Liguri. Memorie della Società Geologica Italiana, 28: 229-265.

Boni A., Cerro A., Gianotti R. and Vanossi M., 1971. Note illustrative carta geologica d'Italia. Foglio 92-93. Albenga - Savona. Servizio Geologico d'Italia, Roma.

Boni P., Mosna S. and Vanossi M., 1968. La "Pietra di Finale" (Liguria Occidentale). Atti Istituto di Geologia dell'Università di Pavia, 18: 102-150.

Bronk Ramsey C., 2003. OxCal Program v3.9, Radiocarbon Accelerator Unit. University of Oxford.

Capelli C., Mannoni T. and Starnini E., 2006. Tecniche produttive, materie prime e provenienza delle ceramiche preistoriche e protostoriche della Liguria. Atti XXXIX Riunione dell'Istituto

ArcheoSciences, revue d'archéométrie, 30, 2006, p. 89-94 
Italiano di Preistoria e Protostoria, Materie prime e scambi nella Preistoria italiana. Firenze 2004. Volume 2. Tipografia Latini, Firenze, 1201-1208.

Cortesogno L. and VAnossi M., 1985. Introduzione alla geologia delle Alpi Liguri. Lavori della Società Italiana di Biogeografia n.s., 9: 1-48.

Ferraris M. and Ottomano C., 1997. Pottery analyses. In R. Maggi, E. Starnini, B. Voytek (eds.), Arene Candide: a functional and environmental assessment of the Holocene sequence (excavations Bernabò Brea-Cardini 1940-50). Memorie dell'Istituto Italiano di Paleontologia Umana, 5: 339-348.

Giammarino S., Giglia G., Capponi G., Crispini L. and Piazza M., 2002. Carta Geologica della Liguria - Scala 1:200000. Lab. Cartografia digitale e GIS del Dipartimento di Scienze della Terra dell'Università di Siena, Litografia Artistica Cartografica, Firenze.
Mannoni T., 1990. Caratterizzazioni petrografiche e tecniche delle ceramiche preistoriche della Pollera. Rivista Ingauna e Intemelia, XLV: 144-145.

Starnini E. and Vicino G., 1993. Segnalazione di un sito neolitico in località S. Sebastiano di Perti (Finale Ligure-SV). Rassegna di Archeologia, 11: 37-43.

Stuiver M., Reimer P. J., Bard E., Beck W., Burr G. S., Hughen K. A., Kromer B., McCormac G., Van der Plicht J. and SPURKs M., 1998. INTCAL98 Radiocarbon age calibration, 24,000-0 cal BP. Radiocarbon 40(3): 1041-83.

Vanossi M., 1990. Guide Geologiche Regionali - Alpi Liguri. Società Geologica Italiana, BeMa., Milano.

Vanossi M., Cortesogno L., Galbiati B., Messiga B. Piccardo G.B. and VANnuCCI R., 1984. Geologia delle Alpi Liguri: dati, problemi, ipotesi. Memorie della Società Geologica Italiana, 28: 5-75. 